J. AMer. Soc. Hort. Sci. 118(3):326-329. 1993.

\title{
Growth, Yield, and Fruit Quality of Nucellar Frost 'Marsh' Grapefruit on Fifteen Rootstocks in Cyprus
}

\author{
C.V. Economides and C. Gregoriou ${ }^{2}$ \\ Agricultural Research Institute, P.O. Box 2016, Nicosia, Cyprus \\ Additional index words. Citrus paradisi, fruit weight, juice content, rind thickness, total acids, soluble solids concentration
}

\begin{abstract}
Tree growth, yield, and fruit quality of nucellar 'Frost Marsh Seedless' grapefruit (Citrus paradisi Macf.) on 15 rootstocks were evaluated under Cyprus conditions. Over the 9-year production period, trees on Palestine sweet lime, the group of rough lemon, and Citrus volkameriana Pasq. were more productive per unit of tree size, and their cumulative yields per tree were significantly higher than those of trees on sour orange, which is the standard rootstock commercially used in Cyprus. Rootstocks affected fruit size and weight, rind thickness, juice content, total soluble solids concentration (SSC), and total acids, but the differences were not large enough to affect the market value of the fruit, On the basis of the results of this trial and because sour orange is highly susceptible to tristeza, the $C$. volkameriana and rough lemon group, which are tolerant to tristeza, should be included in further trial plantings as a potential commercial rootstock.
\end{abstract}

The Mediterranean basin is one of the citrus growing areas that has been less affected by tristeza virus than several other citrusproducing areas. Tristeza was first reported to exist in Italy in 1955 on Meyer lemon and satsuma mandarin (Russo, 1956). Subsequently, other citrus species were found to be infected in various locations (Davino et al., 1984). In Israel, the disease has been spreading since 1970, 20,000 tristeza-infected trees have been uprooted, and the estimations are that 50,000 to 100,000 more trees are infected (Moreno, 1988). In Spain, between 1956 and 1992, $\approx 15$ million trees grafted on sour orange died from tristeza infection, and 7 to 8 million more trees are infected and in different stages of decline (Chambra et al., 1982).

In Cyprus, the presence of tristeza was reported in 1968 by Papasolomontos and Economides (1968) who found 26 trees of four species infected. All diseased trees were eradicated. The use of sour orange as the main rootstock and reports of the spread of tristeza in neighboring countries have necessitated the initiation of indexing work for tristeza. Indexing work on Clementine mandarin trees in the main citrus producing area showed 190 trees infected out of 332 trees tested (Kyriacou and Polycarpou, 1989). A routine indexing and eradication program for tristeza is undertaken in the island's citrus industry.

As an assurance for future plantings, research programs were started in Cyprus (Economides, 1976a, 1976b; Economides, 1977) to find new rootstocks to replace sour orange in case of tristeza outbreak. The rootstocks used in these trials have shown promise in other areas. Performance was measured by growth, yield, and fruit quality of the 'Marsh Seedless' grapefruit as the scion.

\section{Materials and Methods}

The rootstocks included sour orange (C. aurantium L.), Palestine sweet lime (C. limettioides Tan.), rough lemon, Red rough lemon and Estes rough lemon (C. jambhiri Lush.), Rangpur lime (C. limonia Osbeck.), Troyer and Carrizo citrange (C. sinensis (L.) Osbeck $\times$ Poncirus trifoliata (L.) Raf), Yuma citrange (P. trifoliata $\times C$. sinensis), Morton citrange (P. trifoliata $\times C$. sinensis $)$,

Received for publication 1 Apr. 1992. Accepted for publication 24 Oct. 1993. Research conducted at Akhelia Research Station of the Agricultural Research Institute. The cost of publishing this paper was defrayed in part by the payment of page charges. Under postal regulations, this paper therefore must be hereby marked advertisement solely to indicate this fact.

'Senior Agricultural Research Officer.

${ }^{2}$ Agricultural Research Officer 'A'.
'Swingle' citrumelo (C. paradisi $\times P$. trifoliata), Volkameriana $(C$. volkameriana Pasq.), Taiwanica (C. taiwanica Tan.), Amblycarpa (C. limonellus var. amblycarpa Hassk.), and Cleopatra mandarin (C. reticulata Blanko.). Seeds were obtained from California, except those of sour orange and Palestine sweet lime, which were obtained locally from selected healthy trees. All were planted in Spring 1976. The seedlings were transplanted in the nursery row at the Citrus Experiment Station at Akhelia, Paphos, in Spring 1977, and were budded in Mar. 1978 with buds from a single tree of nucellar 'Frost Marsh Seedless' grapefruit raised from budwood imported from California in 1975. The scion of all the trees were of the same clonal strain.

The trees were raised by standard cultural practices. Uniform 1year-old budded trees were planted in Mar. 1979 at the Citrus Experiment Station at Akhelia in a complete randomized block design with two-tree plots of each rootstock and six replications. The spacing was $6.6 \times 4.2 \mathrm{~m}$.

The soil was clayey ( $60 \%$ clay, $25 \%$ silt, $15 \%$ sand), contained $20 \% \mathrm{CaCO}_{3}$, had a $\mathrm{pH}$ value of 8.0 (1 soil : 2.5 water), and an $\mathrm{EC}$, value of $1.5 \mathrm{dS} \cdot \mathrm{m}^{-1}$ throughout the profile.

Orchard care was similar to commercial practice in the area. The orchard was irrigated by under-tree minisprinklers at 25 weekly intervals per year giving $\approx 700 \mathrm{~mm}$ of water. The water had a $\mathrm{pH}$ of 7.6 and an electrical conductivity of $0.7 \mathrm{dS} \cdot \mathrm{m}^{-1}$ and contained an average of $450 \mathrm{ppm}$ total soluble salts, including 53 ppm Cl, 57 ppm Na${ }^{+}, 58$ ppm Ca ${ }^{+2}, 20$ ppm $\mathrm{Mg}^{+2}, 134$ ppm $\mathrm{SO}_{4}$, and 129 ppm $\mathrm{HCO}_{3}$.

The area has an average yearly rainfall of $420 \mathrm{~mm}$, occurring mainly from October to April. Mean maximum air temperature ranges from $17 \mathrm{C}$ in January to $33 \mathrm{C}$ in July, with mean minima from 9 to $21 \mathrm{C}$. Relative humidity ranges from $50 \%$ to $80 \%$ during the winter months and from $60 \%$ to $70 \%$ in the summer.

Annual applications of ammonium sulphate, triple superphosphate, and potassium sulphate were applied in spring, a month before flowering, the amounts increasing progressively each year to reach $3.0,0.5$, and $1.0 \mathrm{~kg}$ per tree, respectively. The orchard was cultivated, pruned, and sprayed with insecticides, fungicides, and nutritional sprays as needed,

In Oct. 1990, the trunk circumference of each tree was measured at a point $15 \mathrm{~cm}$ above the bud union. These measurements have been converted to trunk cross-sectional area (TCSA) (square centimeters), which better depicts relative sizes.

Yields were measured as kilograms of fruit per tree, harvested in the middle of December each year, when the crop was fully 


\begin{tabular}{|c|c|c|c|c|c|c|c|c|c|c|c|c|}
\hline \multirow[b]{2}{*}{ Rootstock } & \multirow{2}{*}{$\begin{array}{l}\text { TCSA } \\
(1990) \\
\left(\mathrm{cm}^{2}\right)^{\mathrm{z}} \\
\end{array}$} & & \multicolumn{6}{|c|}{ Average annual yield per tree $(\mathrm{kg})$} & \multicolumn{2}{|c|}{ 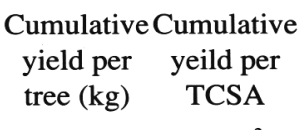 } \\
\hline & & 1982 & 1983 & 1984 & 1985 & 1986 & 1987 & 1988 & 1989 & 1990 & $1982-90$ & $\left(\mathrm{~kg} \cdot \mathrm{cm}^{-2}\right)$ \\
\hline Sour orange & 195 abcd & 12 bcde $^{*}$ & $46 \mathrm{~cd}$ & 93 cde & 143 efg & 90 ghi & $173^{\mathrm{NS}}$ & 252 bcd & $273 \mathrm{ab}$ & 181 cde & $1263 \mathrm{c}$ & $6.5 \mathrm{def}$ \\
\hline \multicolumn{13}{|c|}{ Palestine sweet } \\
\hline lime & 176 cde & $23 \mathrm{ab}$ & $71 \mathrm{ab}$ & $132 \mathrm{a}$ & 185 abcd & $191 \mathrm{a}$ & 204 & $279 a b$ & $287 \mathrm{a}$ & $236 \mathrm{a}$ & $1607 \mathrm{a}$ & $9.1 \mathrm{a}$ \\
\hline Rough lemon & $203 \mathrm{abc}$ & $18 \mathrm{abc}$ & $72 \mathrm{ab}$ & $122 \mathrm{ab}$ & $182 \mathrm{abc}$ & $153 \mathrm{bcd}$ & 156 & $292 \mathrm{ab}$ & $286 \mathrm{a}$ & $225 a b$ & $1505 \mathrm{~b}$ & $7.4 \mathrm{bcd}$ \\
\hline \multicolumn{13}{|l|}{ Red rough } \\
\hline lemon & $210 a b$ & 11 cdef & $61 \mathrm{bc}$ & $106 \mathrm{bc}$ & 162 bcd & $163 \mathrm{abc}$ & 146 & $277 \mathrm{ab}$ & $274 \mathrm{ab}$ & $219 a b$ & $1419 \mathrm{~b}$ & $6.8 \mathrm{cde}$ \\
\hline \multicolumn{13}{|l|}{ Estes rough } \\
\hline lemon & 192 abcd & $23 \mathrm{a}$ & 83 a & $141 \mathrm{a}$ & $194 \mathrm{a}$ & $180 \mathrm{ab}$ & 206 & 297 a & $281 \mathrm{a}$ & $201 \mathrm{bc}$ & $1607 \mathrm{a}$ & $8.4 \mathrm{ab}$ \\
\hline Rangpur lime & $174 \mathrm{de}$ & 4 def & 35 def & 84 def & 147 def & 126 def & 163 & $252 \mathrm{bcd}$ & $240 \mathrm{bc}$ & $184 \mathrm{~cd}$ & $1235 \mathrm{~cd}$ & 7.1 cde \\
\hline Troyer citrange & 181 bcde & 1 ef & $18 \mathrm{~g}$ & $56 \mathrm{hi}$ & $109 \mathrm{~h}$ & 116 efg & 173 & 206 ef & $220 \mathrm{c}$ & 149 efgh & h 1048 e & $5.8 \mathrm{fg}$ \\
\hline \multicolumn{13}{|c|}{ Carrizo } \\
\hline citrange & 174 cde & 15 abcd & $53 \mathrm{c}$ & 104 bcd & 144 defg & $156 \mathrm{bcd}$ & 155 & 226 cde & $218 \mathrm{c}$ & 165 defg & g $1236 \mathrm{~cd}$ & 7.1 cde \\
\hline Yuma citrange & $130 \mathrm{f}$ & $0 \mathrm{f}$ & $15 \mathrm{~g}$ & $38 \mathrm{i}$ & $74 \mathrm{i}$ & $68 \mathrm{i}$ & 164 & $141 \mathrm{~g}$ & $161 \mathrm{~d}$ & $122 \mathrm{~h}$ & $783 \mathrm{f}$ & 6.0 efg \\
\hline Morton citrange & $159 \mathrm{e}$ & 12 bcde & $55 \mathrm{c}$ & 104 bcd & $159 \mathrm{cde}$ & 145 cde & 158 & $255 \mathrm{bcd}$ & $231 \mathrm{c}$ & $185 \mathrm{~cd}$ & $1304 \mathrm{c}$ & $8.2 \mathrm{~b}$ \\
\hline \multicolumn{13}{|c|}{ Swingle } \\
\hline citrumelo & $159 \mathrm{e}$ & 9 cdef & $39 \mathrm{de}$ & 79 efg & $127 \mathrm{fgh}$ & $154 \mathrm{bcd}$ & 174 & $223 \mathrm{de}$ & $218 c$ & $140 \mathrm{gh}$ & $1163 d$ & $7.3 \mathrm{bc}$ \\
\hline Volkameriana & $169 \mathrm{de}$ & $25 \mathrm{a}$ & $76 \mathrm{a}$ & $126 \mathrm{a}$ & $187 \mathrm{ab}$ & $175 \mathrm{abc}$ & 183 & $267 \mathrm{abc}$ & $247 \mathrm{abc}$ & 174 cdef & ef $1461 b$ & $8.7 \mathrm{~b}$ \\
\hline Taiwanica & $171 \mathrm{de}$ & 8 cdef & $37 \mathrm{de}$ & $69 \mathrm{fgh}$ & $119 \mathrm{gh}$ & $82 \mathrm{hi}$ & 157 & 209 ef & $237 \mathrm{bc}$ & 155 efgh & h 1073 e & $6.3 \mathrm{ef}$ \\
\hline Amblycarpa & $207 \mathrm{ab}$ & 2 ef & 28 efg & 73 efgh & 133 efgh & $101 \mathrm{fgh}$ & 178 & 192 ef & $218 \mathrm{c}$ & 134 gh & $1059 \mathrm{e}$ & $5.1 \mathrm{gh}$ \\
\hline \multicolumn{13}{|l|}{ Cleopatra } \\
\hline mandarin & $212 a$ & $1 \mathrm{ef}$ & $23 \mathrm{fg}$ & $60 \mathrm{gh}$ & $106 \mathrm{~h}$ & 72 hi & 179 & $182 \mathrm{f}$ & $221 \mathrm{c}$ & $142 \mathrm{fgh}$ & h 986 e & $4.7 \mathrm{~h}$ \\
\hline CV $(\%)$ & 12 & 79 & 24 & 18 & 14 & 19 & 25 & 13 & 13 & 14 & & \\
\hline
\end{tabular}

${ }^{\mathrm{z}}$ Measured $15 \mathrm{~cm}$ above bud union.

*Mean separation within the same column at $P=0.05$ by Duncan's multiple range test. NS $=$ nonsignificant.

mature. Fruit samples for quality studies, taken from 1986 to 1990 , consisted of a composite of 40 fruits picked at random from the two trees of each replication. Each fruit was weighed and cut in half. Rind thickness was measured with a digital caliper, and the juice was extracted with an electric juicer. Total SSC was measured with a temperature-compensated refractometer, and total acids were determined (as citric acid equivalent) by titrating with $\mathrm{NaOH}$.

\section{Results and Discussion}

After 11 years, the rootstocks had a striking effect on the TCSA (Table 1). The difference between the most vigorous and the least vigorous trees was $\approx 63 \%$, the largest being on Cleopatra mandarin and the smallest on Yuma citrange. Trees on rough lemons, sour orange, and $C$. amblycarpa were larger in general than the trees on citranges and $C$. volkameriana.

The trees on 'Swingle' citrumelo developed a severe overgrowth of the rootstock as compared to the trees on Troyer, Carrizo, Yuma, and Morton citranges on which the overgrowth was slight. The overgrowth of the rootstock did not affect the yield. Some overgrowth of Morton citrange, when used with 'Washington navel', has been reported in California, but the trees looked normal and their performance has not been affected (Batchelor and Rounds, 1948).

Trees on Palestine sweet lime and Troyer citrange showed a general yield increase until 1989 and a decrease in 1990, whereas trees on 'Swingle' citrumelo showed a general yield increase until 1988 and a decrease in the following 2 years (Table 1). Trees on the other rootstocks showed a general yield increase until 1985 and variability in production during the following years. This variabil- ity in production of trees on the various rootstocks probably reflects a tendency to biennial bearing. However, trees on Palestine sweet lime, rough lemons, and $C$. volkameriana had significantly higher yield in almost all years than trees on the other rootstocks.

The cumulative yields over the 9 years from 1982 to 1990 indicate a difference in productivity between the high and the low yielding rootstocks of $105 \%$ (Table 1). The trees on Palestine sweet lime, the rough lemons, and $C$. volkameriana produced significantly higher yields than those on sour orange, the citranges group, and the other rootstocks. The relatively small tree size and low yield of trees on the citranges and 'Swingle' citrumelo were probably due to the high soil $\mathrm{pH}$ and $\mathrm{CaCO}_{3}$ content.

The correlation coefficient between average tree size and cumulative yield was not significant $(r=0.3, P=0.25)$. In general, the largest trees did not produce the highest yields. Productivity per square centimeters of TCSA on the various rootstocks was higher for Palestine sweet lime and $C$. volkameriana and lowest for Cleopatra mandarin and C. amblycarpa (Table 1). The trees on Palestine sweet lime and $C$. volkameriana were medium-sized and could have been planted more closely than the larger trees. With more trees per unit area, the production from medium-sized trees on a per hectare basis may equal or exceed that from trees planted further apart. There are also other disadvantages, including extra cultural costs in handling large trees.

Rootstocks affected fruit size, weight, and rind thickness (Table 2 ). The largest and heaviest fruit was produced by the trees on the rough lemon group, Palestine sweet lime, Rangpur lime, Carrizo citrange, and $C$. volkameriana, although these did not differ significantly from those of all others. Trees on Cleopatra mandarin, C. amblycarpa, C. taiwanica, and Yuma citrange produced 
Table 2. Effect of rootstock on fruit size, weight, and rind thickness of nucellar 'Marsh Seedless' grapefruit (average 1986-90).

\begin{tabular}{lccc}
\hline \hline & $\begin{array}{c}\text { Average fruit } \\
\text { diam } \\
(\mathrm{cm})\end{array}$ & $\begin{array}{c}\text { Average fruit } \\
\mathrm{wt}\end{array}$ & $\begin{array}{c}\text { Average rind } \\
\text { thickness } \\
(\mathrm{m})\end{array}$ \\
Rootstock & $9.5 \mathrm{ab}^{*}$ & $315 \mathrm{bcd}$ & $7.8 \mathrm{abc}$ \\
\hline Sour orange & $9.7 \mathrm{ab}$ & $346 \mathrm{ab}$ & $7.1 \mathrm{c}$ \\
Palestine sweet lime & $9.8 \mathrm{a}$ & $360 \mathrm{a}$ & $7.6 \mathrm{bc}$ \\
Rough lemon & $9.5 \mathrm{ab}$ & $339 \mathrm{ab}$ & $8.0 \mathrm{abc}$ \\
Red rough lemon & $9.7 \mathrm{ab}$ & $335 \mathrm{abc}$ & $7.5 \mathrm{c}$ \\
Estes rough lemon & $9.6 \mathrm{ab}$ & $344 \mathrm{ab}$ & $7.5 \mathrm{c}$ \\
Rangpur lime & $9.0 \mathrm{~cd}$ & $297 \mathrm{cde}$ & $7.8 \mathrm{abc}$ \\
Troyer citrange & $9.5 \mathrm{ab}$ & $338 \mathrm{ab}$ & $7.0 \mathrm{c}$ \\
Carrizo citrange & $9.2 \mathrm{bc}$ & $311 \mathrm{bcde}$ & $8.5 \mathrm{ab}$ \\
Yuma citrange & $9.5 \mathrm{ab}$ & $341 \mathrm{ab}$ & $7.6 \mathrm{bc}$ \\
Morton citrange & $8.9 \mathrm{~cd}$ & $285 \mathrm{de}$ & $7.3 \mathrm{c}$ \\
Swingle citrumelo & $9.6 \mathrm{ab}$ & $332 \mathrm{abc}$ & $7.8 \mathrm{abc}$ \\
Volkameriana & $9.3 \mathrm{abc}$ & $316 \mathrm{bcd}$ & $8.7 \mathrm{a}$ \\
Taiwanica & $9.0 \mathrm{~cd}$ & $276 \mathrm{e}$ & $8.7 \mathrm{a}$ \\
Amblycarpa & $8.7 \mathrm{~d}$ & $277 \mathrm{e}$ & $8.5 \mathrm{ab}$ \\
Cleopatra mandarin & 4.0 & 9.3 & 9.3 \\
CV $(\%)$ & &
\end{tabular}

${ }^{*}$ Mean separation within columns at $P=0.05$ by Duncan's multiple range test.

Table 3. Effect of rootstock on fruit quality of nucellar 'Marsh Seedless' grapefruit (average 1986-90).

\begin{tabular}{|c|c|c|c|c|}
\hline Rootstock & $\begin{array}{c}\text { Juice by } \\
\text { wt } \\
(\%)\end{array}$ & $\begin{array}{c}\text { Total soluble } \\
\text { solids (SSC) } \\
(\%)\end{array}$ & $\begin{array}{c}\text { Total acids } \\
\text { (TA) } \\
(\%)\end{array}$ & $\begin{array}{l}\text { SSC : TA } \\
\text { ratio }\end{array}$ \\
\hline Sour orange & $45.5 \mathrm{a}^{*}$ & $12.2 \mathrm{abc}$ & $2.3 \mathrm{bc}$ & $5.35 \mathrm{bcd}$ \\
\hline Palestine sweet lime & $44.8 \mathrm{ab}$ & $10.1 \mathrm{f}$ & $2.0 \mathrm{~d}$ & $5.07 \mathrm{de}$ \\
\hline Rough lemon & 40.4 cdef & $11.1 \mathrm{def}$ & $2.0 \mathrm{~d}$ & $5.55 \mathrm{bc}$ \\
\hline Red rough lemon & 41.5 bcde & 10.7 ef & $2.0 \mathrm{~d}$ & $5.26 \mathrm{bcd}$ \\
\hline Estes rough lemon & 38.7 efg & $11.3 \mathrm{cde}$ & $2.1 \mathrm{~cd}$ & $5.35 \mathrm{bcd}$ \\
\hline Rangpur lime & 41.6 bcde & 10.7 ef & $2.1 \mathrm{~cd}$ & $5.18 \mathrm{~cd}$ \\
\hline Troyer citrange & 40.4 cdef & 11.7 abcde & $2.3 \mathrm{bcd}$ & $5.19 \mathrm{~cd}$ \\
\hline Carrizo citrange & 39.2 defg & 11.4 bcde & $2.1 \mathrm{~cd}$ & $5.34 \mathrm{bcd}$ \\
\hline Yuma citrange & 41.5 bcde & $11.7 \mathrm{abcd}$ & 2.2 bcd & $5.29 \mathrm{bcd}$ \\
\hline Morton citrange & $43.9 \mathrm{abc}$ & $12.0 \mathrm{abcd}$ & $2.0 \mathrm{~d}$ & $5.93 \mathrm{a}$ \\
\hline Swingle citrumelo & 42.9 abcd & $12.4 \mathrm{ab}$ & $2.3 \mathrm{bc}$ & $5.40 \mathrm{bcd}$ \\
\hline Volkameriana & $37.2 \mathrm{fg}$ & 11.5 bcde & $2.1 \mathrm{~cd}$ & $5.58 \mathrm{~b}$ \\
\hline Taiwanica & 40.6 cdef & $11.2 \mathrm{cde}$ & $2.2 \mathrm{bcd}$ & $5.17 \mathrm{~d}$ \\
\hline Amblycarpa & $37.1 \mathrm{fg}$ & $12.6 \mathrm{a}$ & $2.7 \mathrm{a}$ & $4.77 \mathrm{e}$ \\
\hline Cleopatra mandarin & $36.4 \mathrm{~g}$ & $12.3 \mathrm{abc}$ & $2.4 \mathrm{~b}$ & $5.15 \mathrm{~d}$ \\
\hline CV $(\%)$ & 6.2 & 6.8 & 8.7 & 5.3 \\
\hline
\end{tabular}

${ }^{*}$ Mean separation within columns at $P=0.05$ by Duncan's multiple range test.

fruit with thicker rinds than trees on other rootstocks, but they were similar to those of fruit on others.

Fruit quality was also influenced by rootstock (Table 3 ). Juice content per unit fruit weight was higher for trees on sour orange and Palestine sweet lime and lower for those on $C$. volkameriana, $C$. amblycarpa, and Cleopatra mandarin than for most others. Total SSC was higher in fruit from trees on sour orange, 'Swingle' citrumelo, C. amblycarpa, Cleopatra mandarin and lower from trees on Rangpur lime, Red rough lemon, Palestine sweet lime, and Rough lemon than for most others. There was no great variation in total acids content in fruit from trees on various rootstocks. In general, the differences in total SSC and total acids were not large enough to be likely to affect the market value of the fruit when harvested at dates used in this study.

Cyprus citriculture is threatened by tristeza, and the tristeza- susceptible sour orange rootstock should be replaced by other rootstock(s) resistant to the disease. Choice of a rootstock becomes a matter of individual judgment when the merit of a rootstock depends on several characteristics and when none is superior in all respects. Citrus volkameriana and the rough lemons, which are tolerant to tristeza, would appear to be the best of those evaluated. Trees on these rootstocks produce large yields of fruit (per tree) of excellent size and of average total SSC and total acids content. Although juice content per unit fruit weight was low for trees on C. volkameriana, this rootstock is adaptable to a wide range of soils and would be suitable for use under most conditions (Castle et al., 1989).

On the basis of these results, $C$. volkameriana and the rough lemons deserve further evaluations as potential commercial rootstocks to replace the tristeza-susceptible sour orange root- 
stock. Risks are of course unavoidable in the adoption of any new fruit rootstocks, and final conclusion will emerge only after extended trials and experience under a range of commercial growing conditions.

\section{Literature Cited}

Batchelor, L.D. and M.D. Rounds. 1948. Choice of rootstocks, p. 169222. In: L.D. Batchelor and H.J. Webber (eds.). The Citrus Ind. vol II, Univ. of California Press, Berkeley.

Castle, S.W., D.P.H. Tucker, H.A. Krezdorn, and C.O. Youtsey. 1989. Rootstocks for Florida Citrus. Inst. Food Agr. Sci., Univ. of Florida, Gainesville, pp. 47.

Chambra, M., A. Hermoso, P. Moreno, and L. Navarro. 1982. Use of enzyme-linked immunosorbent assay (ELISA) for detection of citrus tristeza virus (CTV) in different aphid. Proc. Intl. Soc. Citricult. 1:444448.

Daviono, M., A. Catara, F. Russo, G. Terranova, and G. Carbone. 1984. A survey for citrus tristeza virus in Italy by the use of enzyme-linked immunosorbent assay. Proc. 9th Conf. Intl. Organization Citrus Virologists, Riverside, 66-69.

Economides, C.V. 1976a. Performance of Marsh seedless grapefruit on six rootstocks in Cyprus. J. Hort. Sci. 51:393-400.

Economides, C.V. 1976b. Growth and productivity of Washington navel orange trees on six rootstocks in Cyprus. Hort. Res. 16:83-88.

Economides, C.V. 1977. The influence of rootstocks on tree growth, yield and fruit quality of Valencia oranges in Cyprus. J. Hort. Sci. 52:29-36. Kyriacou, A. and D. Polycarpou. 1989. Detection of Citrus tristeza in Cyprus. Mediterranean Crop Improvement Council, News 12:3-4.

Moreno, P. 1988. Citrus tristeza virus (CTV). A major threat to the Mediterranean area. Working group. Integrated control in citrus fruit crops. Intl. Union Biol. Sci. 100-108.

Papasolomontos, A and C.V. Economides. 1968. The presence of tristeza virus in certain species of citrus in Cyprus. Food Agr. Organization Plant Protection Bul. 16 (1):8-9.

Russo, F. 1956. La presenza del virus della tristeza su limon "Dwarf Meyer" emandarino "Satsuma"riscontrata in Sicilia. Riv Agromicoltura 1:7-8,281-289. 